\title{
A case of Miller Fisher syndrome with progression and early relapse
}

\author{
Progresyon ve erken relapsla seyreden bir Miller Fisher sendromu olgusu \\ Volkan Solmaz, Dürdane Aksoy*, Betül Çevik, Semiha Kurt, Emre Çevik, \\ Elmas Pekdaș
}

Department of Neurology (V. Solmaz, MD., Assist. Prof. D. Aksoy, MD., Assist. Prof. B. Çevik, MD., Assoc. Prof. S. Kurt, MD., E. Çevik, MD., E. Pekdaş, MD.), Gaziosmanpaşa University, School of Medicine, TR-60250 Tokat

\begin{abstract}
Miller Fisher syndrome (MFS) is one of the rare variants of the Guillain-Barre syndrome. Charles Miller Fisher expressed the disease to be a Guillain-Barre variant with a good prognosis, that is accompanied by ataxia, ophthalmoplegia and areflexia. While it is generally monophasic, some cases with recurrences were also reported in literature. This article presents a 73-year-old male patient who was admitted to our clinic with ataxia, ophthalmoplegia, areflexia and paresthesia. No abnormality was detected in the complete blood count, routine biochemistry, erythrocyte sedimentation rate, C-reactive protein, thyroid function tests and serum vitamin B12 and folate levels, tests for hepatitis A, B and other viral markers; brain and cervical magnetic resonance images (MRI) were also normal. Electroneurography revealed the absence of the median, ulnar, peroneal and the tibial F waves. Anti-GQ1b antibody was positive in the patient's serum. He was hospitalized with the diagnosis of MFS, and he subsequently developed tetraparesis in the following a few days, and had a relapse in the early period. Seven-day intravenous immunoglobulin (IVIG) treatment which was given to the patient after hospitalization, was repeated upon the patient's relapse on the 30th day of his admission. A partial recovery of the patient's symptoms was observed after these treatments. Although there have been studies suggesting that the prognosis of MFS is good, progression or early relapses can be seen during the course of the disease; and as in this case, the repeated IVIG treatment can affect the course of the disease positively. Therefore, it is important to keep these rare conditions in mind during followup of patients diagnosed with MFS.
\end{abstract}

Keywords: Miller Fisher Syndrome, Guillain-Barre Syndrome, Intravenous immunoglobulin

\section{Özet}

Miller Fisher sendromu (MFS), Guillain-Barre sendromunun ender varyantlarından bir tanesidir. Charles Miller Fisher tarafindan hastalığın ataksi, oftalmoparezi, arefleksi triadıyla giden iyi prognozlu bir Guillain-Barre varyantı olduğu ifade edilmiş̧ir. Genellikle monofazik olmakla birlikte literatürde rekürrenslerle giden vakalar da bildirilmiştir. Bu yazıda kliniğimize ataksi, oftalmoparezi, arefleksi ve parestezilerle başvurup MFS tanısıyla yatırılan, takip eden birkaç gün içinde tetraparezisi gelişen ve erken dönemde relaps meydana gelen 73 yaşında bir erkek hasta sunuldu. Hastanın tam kan sayımı, rutin biyokimya, eritrosit sedimantasyon hızı, C-reaktif protein, tiroid fonksiyon testleri, serum vitamin B12 ve folat düzeyleri, Hepatit B, Hepatit C ve diğer viral belirteçlerinde anormallik yoktu, ayrıca beyin ve servikal manyetik rezonans imajları (MRI) normaldi. Elektronörografide median, ulnar, peroneal ve tibial F yanttları elde edilemedi. Serum anti-GQ1 antikoru pozitifti. Hasta MFS tanısı ile yatırıldı, sonraki bir kaç gün içerisinde tetraparezi gelişti ve erken dönemde relaps gözlendi. Hastaya servisimize yatışının ardından verilen 7 günlük intravenöz immünglobulin (IVIG) tedavisi, yatışının 30. gününde relaps gelişmesi üzerine tekrarlandı. Bu tedavilerden sonra hastanın belirtilerinde kısmi bir düzelme gözlendi. MFS'nin prognozunun iyi olduğunu ifade eden çalışmalara rağmen hastalığın seyrinde bu vakada olduğu gibi progresyon veya erken relapslar görülebilir ve tekrarlanan IVIG tedavisi hastalığın seyrini olumlu etkileyebilir. Dolayısıyla MFS tanısı alan hastaların takibinde, tanımlanan bu nadir durumların akılda tutulması önemlidir.

Anahtar sözcükler: Miller Fisher Sendromu; Guillain-Barre Sendromu; İntravenöz immünglobulin 
Geliş tarihi/Received: October 09, 2012; Kabul tarihi/Accepted: April 15, 2013

\section{*Corresponding author:}

Dr. Dürdane (Bekar) Aksoy, Nöroloji Anabilim Dalı, Gaziosmanpaşa Üniversitesi Tıp Fakültesi, TR-60250 Tokat. E-mail: dbekar@yahoo.com

\section{Introduction}

Guillain-Barre syndrome is an acute inflammatory demyelinating ascending polyradiculoneuropathy. Its incidence is estimated to be 0.2-4/100,000 [1]. Miller Fisher Syndrome (MFS) constitutes approximately 5\% of all cases of Guillain-Barre Syndrome [2]. It is reported in the literature that patients with MFS generally have good prognosis and rarely develop recurrences $[2,3]$. Electrophysiological findings may not be identified during the acute phase of the disease; however, in following phases, the symptoms of sensorimotor polyneuropathy might be detected in electroneuromyography (ENMG) [3]. Here, we present a case who was followed with the diagnosis of MFS in our clinic and showed progression.

\section{Case report}

A 73 year-old male patient had complaints of numbness of his hands and feet, loss of balance, and ptosis one day before admitting to our clinic. He was sent from another hospital to our emergency clinic with the pre-diagnosis of Guillain-Barre Syndrome. He reported that he had had gastroenteritis approximately 10 days before the beginning of his complaints. Cranial nerve examination of the patient performed in the emergency clinic revealed bilateral ptosis, weakness of the direct and the indirect light reflexes, evident limitation of the eye movements regarding upward, downward, right, and left gaze, bilateral papilledema, and a mild dysphagia. His sensorimotor examination showed that the strength of his four extremities was at the level of $-5 / 5$ with a stocking and glove hypoesthesia. Areflexia of the upper and the lower extremities, as well as an evident ataxia, were detected. His medical history was non-contributory except for hypertension and his family history was also non-contributory. As the patient had risk factors such as advanced age and hypertension, for differential diagnosis, we performed contrastenhanced and unenhanced brain and cervical magnetic resonance images (MRI) which revealed no pathology. No abnormality was detected in the complete blood count, routine biochemistry, erythrocyte sedimentation rate, C-reactive protein, thyroid function tests, vitamin B12, folate, Hepatitis B, Hepatitis C and other viral indicators, but anti-GQ1b antibody was detected in his serum. The lumbar puncture, that was planned for diagnosis, could not be performed upon the rejection of the patient. The sensorial responses of the bilateral median and the ulnar nerves, and the $\mathrm{F}$ responses of the bilateral median, ulnar, posterior tibial and the peroneal nerves could not be obtained in ENMG, which was performed for the pre-diagnosis of the Guillain-Barre syndrome. Due to the existence of ataxia, ophthalmoplegia, areflexia, and the electrophysiological and the serological findings, the patient was diagnosed with the Miller Fisher variant of the Guillain-Barre syndrome and the motor deficit of the patient increased on the second day of his hospitalization.

The patient was treated with $0.4 \mathrm{gr} / \mathrm{kg} /$ day of intravenous immunoglobulin (IVIG) for 7 days and he was included in the rehabilitation program. While his motor power receded to the levels of $-2 / 5$ before the treatment, it increased to $+3 / 5$ after the treatment. The patient, who had sudden bradycardia and hypotension attacks on the 5th day of his hospitalization, was thought to have involvement of autonomic nervous system and taken into the intensive care unit where he was followed for 8 days. The patient, who was not in need of mechanic ventilator and had stable vital symptoms and motor powers in his intensive care follow-ups, was taken back to the neurology service. On the 30th day of his 
hospitalization, his motor powers receded to the levels of $1 / 5$ once again. In the repeated ENMG, the motor conduction speeds decelerated on the upper and the lower extremity nerves, the sensorial responses of the median and the ulnar nerve could not be obtained bilaterally and conduction blockages were detected on the ulnar nerve and the peroneal nerve. The patient was treated with IVIG again for 5 days, upon the progression of clinical findings.

Thorax computed tomography, abdominal ultrasonography, carcinoembryonic antigen (CEA), cancer antigens CA 19-9, CA 125, CA 15-3 and alpha feto-protein levels, which were performed considering a malignancy could be accompanied by MFS, were within normal limits. Following the repeated IVIG treatment, the motor powers of the patient was improved to $-4 / 5$ on the upper and the lower extremities. During follow-up, the gaze paralysis and the ptosis of the patient recovered partially. The motor examination was at the level of $-4 / 5$ on the upper and the lower extremities again and the deep tendon reflexes started to be received hypoactively a few weeks later. The patient, showing a partial recovery of his ataxia, was transferred to the Physical Therapy and Rehabilitation Clinic at the end of the second month of his hospitalization.

\section{Discussion}

MFS was described by Collier in 1932 as a variant of the Guillain-Barre spectrum [1-4]. The classic triad of the disease was defined by Charles Miller Fisher as ataxia, ophthalmoplegia and areflexia in 1956 [3]. The existence of systemic infections such as gastrointestinal system or upper respiratory tract infections before the appearance of the clinical picture is known $[5,6]$. The initial complaints of our patient were ataxia, ptosis and ophthalmoplegia, followed by a mild dysphagia. Cerebrovascular disease or other intracranial lesions, which were considered due to the existence of risk factors such as hypertension and advanced age, were excluded by brain MRI, and the identified symptoms were associated with the cranial nerve involvement caused by MFS. Ophthalmoplegia in MFS is a symptom, which emerges during the acute phase of the disease and has the strongest relation with the syndrome [7]. While symptoms are seen bilaterally and symmetrically in many patients, they might rarely be unilateral $[7,8]$. Besides, it was indicated that at least one of other cranial nerves, except for the oculomotor nerve, was involved in 57\% of cases with MFS [9]. Another clinical symptom in MFS triad is ataxia, which is thought to be associated with both central and peripheral reasons $[9,10]$. It was reported that ataxia occurs as a result of the nonadherence of proprioceptive knowledge about muscle spindles, joints and other proprioceptors $[8,9$, $11,12]$. Even though areflexia is amongst the classical triad of MFS, it might not always be present $[1,6]$. Other than these three symptoms, some other symptoms such as ptosis, dysesthesia, facial or bulbar paralysis, optic neuritis, headache, urinary retention, subclinical or clinical autonomic dysfunction have also been reported [1, 6, 13]. Our case has other symptoms such as paracetamol-responsive headache, dysphagia, papilledema, bradycardia, and hypotension. Anti-GQ1b antibody is a powerful diagnostic marker for MFS and it was positive in this case [1,7].

Today, the commonly applied treatments of MFS include IVIG, plasmapheresis, rehabilitation, and symptomatic treatments [4, 14]. In a series of 92 cases, the effectiveness of IVIG treatment and plasmapheresis was compared. The comparison concluded that these two treatments had no superiority to each other [13]. This could be due to the fact that the disease has a good natural prognosis. In the same study, the period from the beginning of neurological symptoms to the beginning of recovery was 12 days for ataxia and 15 days for ophthalmoplegia for the patients, who were diagnosed with MFS and left untreated [13]. Even though there was a partial response to the IVIG treatment given at the beginning of his symptoms in our case, there was not a complete recovery. However, a better response was received for the second IVIG treatment, which was given upon the relapse of the patient's symptoms. As opposed to the cases reported in the literature, an early relapse occurred in our patient and we could not get a complete 
clinical recovery. This condition suggests that there might not be a complete recovery in MFS and indeed, relapses might occur in early period.

Consequently, MFS is a rare variant of the Guillain-Barre syndrome. Although in the literature there are studies indicating that the prognosis of the MFS is very good, progression or early relapses could be observed in the course of disease. The repeated IVIG treatment might positively affect the course of disease.

\section{References}

1. Ito M, Kuwabara S, Odaka M, Misawa S, Koga M, Hirata K, Yuki N. Bickerstaff's brainstem encephalitis and Fisher syndrome form a continuous spectrum: clinical analysis of 581 cases. J Neurol 2008; 255: 674-82.

2. Takano H, Yuki N. Fisher's syndrome associated with chickenpox and anti-GQ1b antibody. J Neurol 1995; 242: 255-6.

3. Fisher M. An unusual variant of acute idiopathic polyneuritis (syndrome of ophthalmoplegia, ataxia and areflexia). N Engl J Med 1956; 255: 57-65.

4. Seneviratne U. Guillain-Barré syndrome. Postgrad Med J 2000; 76: 774-82.

5. Smith J, Clarke L, Severn P, Boyce R. Unilateral external ophthalmoplegia in Miller Fisher syndrome: case report. BMC Ophtalmol 2007; $7: 7$.

6. Takahashi M, Koga M, Yokoyama K, Yuki N. Epidemiology of Campylobacter jejuni isolated from Patients with Guillain-Barré and Fisher Syndromes in Japan. J Clin Microbiol 2005; 43: 335-9.

7. Susuki K, Yuki N, Muramatsu M, Hirata K. Unilateral ophthalmoparesis and limb ataxia associated with anti-GQ1b IgG antibody. J Neurol 2000; 247: 652-3.

8. Weiss JA, White JC. Correlation of 1a afferent conduction with the ataxia of Fisher syndrome. Muscle Nerve 1986; 9: 327-32.

9. Snyder LA, Rismondo V, Miller NR. The Fisher variant of Guillain-Barré syndrome (Fisher syndrome). J Neuroophthalmol 2009; 29: 312-24.

10. Nishimoto $\mathrm{Y}$, Odaka M, Hirata K, Yuki N. Usefulness of anti-GQ1b IgG antibody testing in Fisher syndrome compared with cerebrospinal fluid examination. J Neuroimmunol 2004; 148: 200-5.

11. Lo YL. Clinical and immunological spectrum of the Miller Fisher syndrome. Muscle Nerve 2007; 36: 615-27.

12. Li H, Yuan J. Miller Fisher syndrome: toward a more comprehensive understanding. Chin Med J 2001; 114: 235-9.

13. Mori M, Kuwabara S, Fukutake T, Yuki N, Hattori T. Clinical features and prognosis of Miller Fisher Syndrome. Neurology 2001; 56: 1104-6.

14. Mori M, Kuwabara S, Fukutake T, Hattori T. Plasmapheresis and Miller Fisher syndrome: analysis of 50 consecutive cases. J Neurol Neurosurg Psychiatry 2002; 72: 680 . 